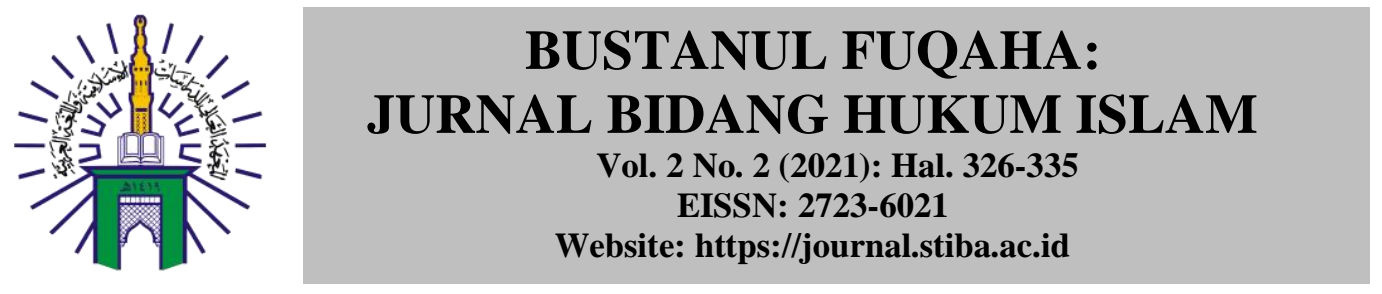

\title{
PRAKTIK KHITAN DENGAN METODE SUNATHRONE KLAMP PERSPEKTIF HUKUM ISLAM (STUDI KASUS DI SMART CARE CENTER MAKASSAR)
}

\section{PRACTICE OF CIRCUMCISION WITH THE SUNATHRONE KLAMP METHOD ISLAMIC LAW PERSPECTIVE (CASE STUDY AT SMART CARE CENTER MAKASSAR)}

\section{Rachmat Bin Badani Tempo}

Sekolah Tinggi Ilmu Islam dan Bahasa Arab (STIBA) Makassar

Email: rachmatbadani@stiba.ac.id

\section{Santi Sarni}

Sekolah Tinggi Ilmu Islam dan Bahasa Arab (STIBA) Makassar

Email: santisarni@stiba.ac.id

\section{Sri Ujiana Putri}

Sekolah Tinggi Ilmu Islam dan Bahasa Arab (STIBA) Makassar

Email: sri.ujiana@stiba.ac.id

\section{Nur Fadhilah}

Sekolah Tinggi Ilmu Islam dan Bahasa Arab (STIBA) Makassar Email: nur.fadhilah9@gmail.com

\begin{tabular}{|c|c|}
\hline Keywords : & ABSTRACT \\
\hline $\begin{array}{l}\text { Circumcision, Sunathrone } \\
\text { Klamp Method, Islamic Law. }\end{array}$ & $\begin{array}{l}\text { This study aimed to examine the practice of circumcision using the } \\
\text { Sunathrone Klamp method at the Makassar Smart Care Center Clinic in } \\
\text { a review of Islamic law. This research used field research using } \\
\text { normative theological approaches and health approaches. Data } \\
\text { collection techniques were conducted through observation, interviews, } \\
\text { and documentation. The research results found; 1) The healing process } \\
\text { of the circumcision wound has a phase in } 3 \text { weeks (21 days), in which } \\
\text { the skin will return to its original shape. There are three phases of wound } \\
\text { healing after circumcision using the Sunathrone Klamp method, namely } \\
\text { the inflammation phase, the proliferation phase, and the remodeling } \\
\text { phase; 2) The advantages of the Sunathrone Klamp include a relatively } \\
\text { short time, no stitches, minimizing pain, psychologically the child feels } \\
\text { comfortable when circumcised, and relatively fast healing time. The } \\
\text { drawbacks after circumcision are that the patient feels uncomfortable } \\
\text { because the clamp will be installed in a few days, and has a high level } \\
\text { of operational standards, so that it is only used by experts in the field; } \\
\text { and 3) Sunathrone Klamp is a practical tool for circumcision or } \\
\text { circumcision with an easier, safer, and hygienic working process. In a } \\
\text { review of Islamic law, the Sunathrone Klamp method is permissible, as } \\
\text { long as the circumcision process is carried out by an expert or } \\
\text { professional. }\end{array}$ \\
\hline \multirow{2}{*}{$\begin{array}{l}\text { Kata kunci : } \\
\text { Khitan, Metode Sunathrone } \\
\text { Klamp, Hukum Islam. }\end{array}$} & ABSTRAK \\
\hline & $\begin{array}{l}\text { Penelitian ini bertujuan untuk mengkaji praktik khitan menggunakan } \\
\text { metode Sunathrone Klamp di Klinik Smart Care Center Makassar dalam }\end{array}$ \\
\hline
\end{tabular}




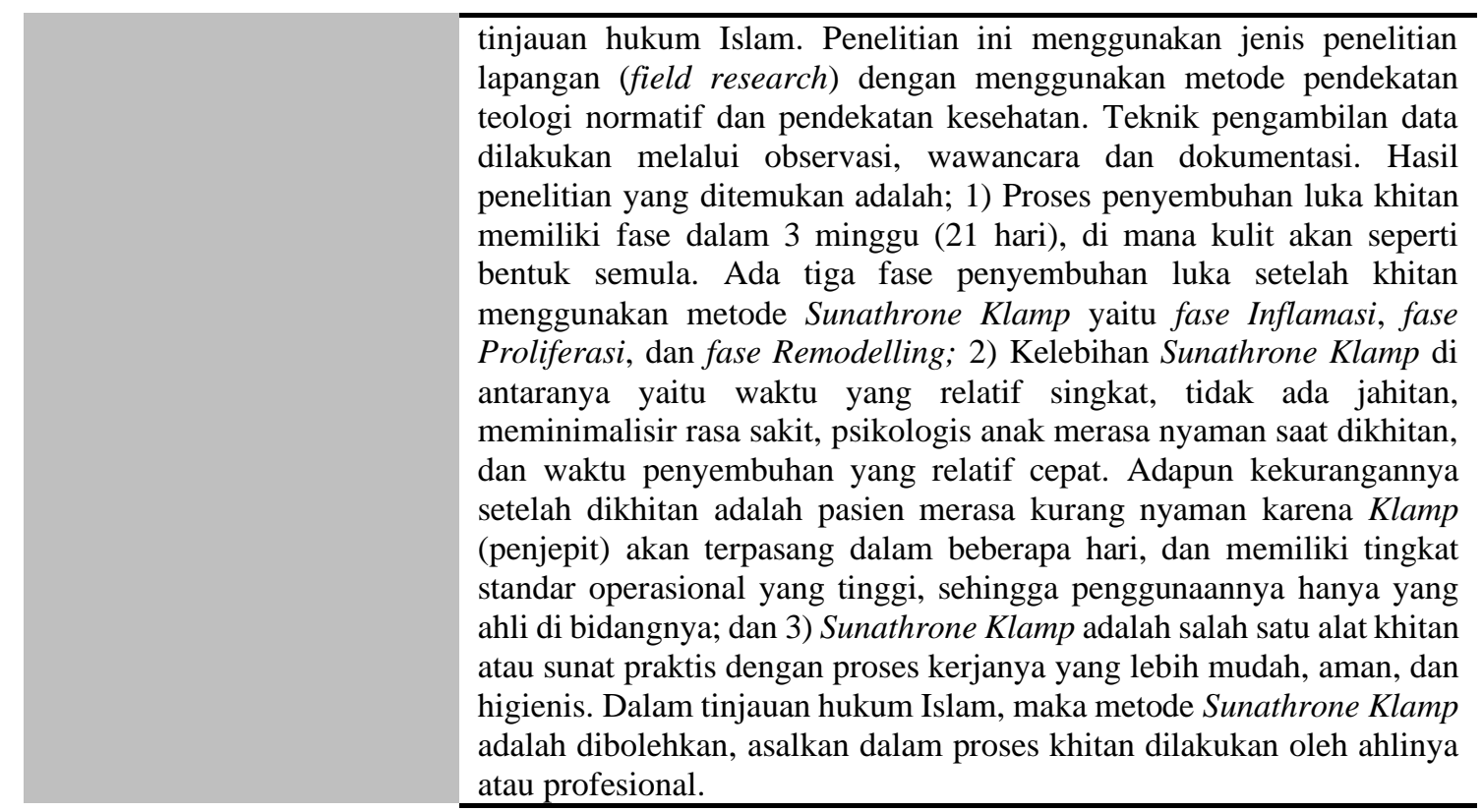

Diterima: 13 Agustus 2021; Direvisi: 18 Agustus 2021; Disetujui: 18 Agustus 2021; Tersedia online: 20 Agustus 2021

How to cite: Rachmat Bin Badani Tempo, Santi Sarni, Sri Ujiana Putri, Nur Fadhilah, "Praktik Khitan dengan Metode Sunathrone Klamp Perspektif Hukum Islam (Studi Kasus di Smart Care Center Makassar)", BUSTANUL FUQAHA: Jurnal Bidang Hukum Islam 2, No. 2 (2021): 326-335. doi: 10.36701/bustanul.v2i2. 366.

\section{PENDAHULUAN}

Sesungguhnya Islam telah mengajarkan kepada umatnya tentang sunah-sunah fitrah. Sunah-sunah fitrah yang dimaksud adalah sunah para nabi terdahulu yang terkait dengan kesucian baik yang lahir maupun yang batin. Rasulullah saw. bersabda yang artinya, "Fitrah manusia ada lima perkara atau lima perkara yang merupakan fitrah manusia, yaitu khitan, al-Istihdād (mencukur rambut pada sekitar kemaluan), mencukur bulu ketiak, menggunting kuku, dan memotong kumis" (HR. Muslim) ${ }^{1}$. Islam telah mempertegas akan pentingnya berkhitan yakni untuk bersuci dan menjaga kesucian ${ }^{2}$.

Khitan adalah salah satu aspek penting dalam taharah (kesucian dan kebersihan) yang sangat ditekankan dalam syariat Islam. Ketika Kulup (penutup kepala penis) tidak dikhitan, maka air kencing dan kotoran lain dapat menggumpal di bawah lipatan kulit. Daerah ini rentan terinfeksi dan mendatangkan penyakit karena menjadi tempat pertumbuhan bakteri ${ }^{3}$. Khitan dalam bagian fitrah menandakan bahwa khitan merupakan amalan yang sederhana yang berdimensi kebersihan fisik. Niat dilaksanakannya khitan hendaknya untuk mencapai fitrah yaitu kebersihan fisik dan psikis serta mengikuti sunah

\footnotetext{
${ }^{1}$ Sayyid Sābiq, Fiqih al-Sunah, Juz 1 (Cet. V; Bairut: Dār al-Fikr,1971 M/1391 H), h. 34.

${ }^{2}$ Abu Bakar Ahmad bin Ali al-Baihaqi, Sunan al-Kubra, Juz 8 (Beirut: Dār al-Fikr,t.t), h.324.

${ }^{3}$ Norma Tarazi, Wahai Ibu Kenali Anakmu: Pegangan Orang Muslim Mendidik Anak, (Cet. I; Yogyakarta: Mitra Pustaka, 2001), h.12.
} 
para nabi. Khitan juga banyak memberikan manfaat dari sisi kesehatan. Hal ini ditengarai bahwa banyak penyakit yang bisa tercegah dengan khitan.

Masyarakat muslim khususnya di Indonesia telah melakukan proses khitan ini sejak dahulu dengan menggunakan metode konvensional. Dalam hal ini khitan dilakukan bukan berasal dari tenaga kesehatan. Umumnya khitan dilakukan tanpa peralatan medis, dan tidak adanya perawatan luka secara khusus, sebagaimana dalam beberapa tradisi masyarakat di Indonesia ${ }^{4}$. Akibatnya, komplikasi yang mungkin timbul adalah infeksi pada luka khitan karena proses yang kurang steril dan luka khitan yang tidak rapi. Sedangkan khitan dengan medis merupakan khitan yang dilakukan oleh tenaga kesehatan, ahli dibidangnya atau profesional. Namun, bila dalam prosesnya ada yang kurang steril, maka kecenderungannya sangat memungkinkan akan terjadi komplikasi infeksi, baik itu peralatan, tenaga maupun alat khitan seperti Klamp.

Seiring dengan semakin berkembangnya teknologi dan ilmu pengetahuan terutama di bidang kesehatan, maka metode khitan pun semakin berkembang. Saat ini telah diciptakan banyak peralatan dan obat-obatan untuk membantu melaksanakan khitan, sehingga khitan menjadi proses yang lebih aman dan lebih tidak menyakitkan. Selain itu, banyak pula metode yang mulai dikembangkan dalam pelaksanaan khitan sehingga prosesnya menjadi lebih mudah dan lebih cepat. Semuanya memiliki kelebihan dan kekurangan masing-masing. Di antaranya adalah metode konvensional dan metode tradisional. Metode konvensional adalah teknik khitan yang dilakukan oleh mantri dan dokter, kemudian metode laser yaitu metode yang dilakukan dengan menggunakan medium logam. Adapun metode tradisional adalah teknik yang umumnya dilakukan oleh mantri sunat dengan menggunakan alat potong sederhana tetapi tajam ${ }^{5}$. Sementara itu inovasi lainnya telah dikembangkan yaitu metode Sunathrone Klamp yaitu perangkat khitan yang sangat praktis dengan penyembuhannya yang baik dan relatif cepat ${ }^{6}$, sehingga pasien tidak perlu khawatir untuk proses penyembuhannya serta aktivitas dapat kembali dilakukan pasca khitan.

Praktik khitan dengan metode Sunathrone Klamp masih banyak menuai pro dan kontra bagi masyarakat muslim di Indonesia khususnya di Kota Makassar Provinsi Sulawesi Selatan. Metode khitan ini telah dipraktikkan di Smart Care Center Makassar. Permasalahan yang timbul adalah Sunathrone dianggap sebagai metode modern yang dilakukan oleh orang-orang barat. Permasalahan lainnya adalah adanya persepsi yang salah terhadap metode Sunathrone Klamp, hal ini disebabkan oleh kurangnya edukasi kepada masyarakat akibat minimnya publikasi dan referensi bacaan mengenai khitan dengan metode ini.

Atas dasar asumsi tersebut, maka penulis tertarik untuk melakukan pengkajian terhadap nomena metode Sunathrone Klamp, kaitannya dengan perspektif hukum Islam.

\footnotetext{
${ }^{4}$ Hajrah, Hajrah. Khitan (Sunna) dalam Upacara Adat di Desa Bontocini Kabupaten Jeneponto. Diss. Universitas Islam Negeri Alauddin Makassar, 2017.

5 Sulahyuningsih, Evie, Yasinta Aloysia Daro, and Alfia Safitri. "Analisis Praktik Tradisional Berbahaya: Sunat Perempuan Sebagai Indikator Kesetaraan Gender dalam Perspektif Agama, Transkultural, dan Kesehatan Reproduksi di Kabupaten Sumbawa. "Jurnal Ilmu Keperawatan dan Kebidanan 12.1 (2021): 134-148.

6 Omar Al Hussein Alawamlh, et al. "Novel devices for adolescent and adult male circumcision." European urology focus 4.3 (2018): 329-332.
} 


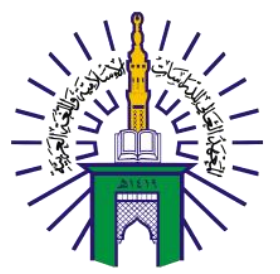

\section{BUSTANUL FUQAHA: \\ JURNAL BIDANG HUKUM ISLAM \\ Vol. 2 No. 2 (2021): Hal. 326-335 \\ EISSN: 2723-6021 \\ Website: https://journal.stiba.ac.id}

Untuk itu, permasalahan yang diangkat dalam penelitian ini adalah; 1) Bagaimana gambaran praktik khitan dengan metode Sunathrone Klamp?; 2) Bagaimana kelebihan dan kekurangan metode Sunathrone Klamp terhadap khitan?; 3) Bagaimana pandangan hukum Islam terhadap praktik khitan dengan metode Sunathrone Klamp?. Penelitian ini menggunakan jenis penelitian lapangan (field research) dengan menggunakan metode pendekatan teologi normatif dan pendekatan kesehatan. Teknik pengambilan data melalui observasi, wawancara dan dokumentasi.

Untuk mendukung penelaahan yang komprehensif, maka perlu dilakukan kajian awal terhadap pustaka atau karya-karya yang mempunyai relevansi terhadap topik yang akan dikaji, seperti buku Al-Fawāid al-Hisān Fi Ahkāmil Khitān ${ }^{7}$, karya Syaikh Sultan bin Ali bin Tsabit al-Jaradi. Buku ini berisi pembahasan hukum mengenai khitan. Kelebihannya buku ini ditulis dengan sangat terperinci mulai dari pengertian, sejarah khitan, pendapat para ulama terhadap masalah-masalah terkait dengan khitan. Buku Fiqih al-Sunah ${ }^{8}$, Karya Syaikh Sayyid Sabiq. Buku ini membahas masalah-masalah fikih Islam disertai dalil-dalil keterangan yang bersumber dari kitab suci Al-Qur'an dan sunah Nabi saw. yang shahih, begitupun ijmak ulama, dikupas dari berbagai perspektif dengan landasan yang detail. Buku Hukum dan Panduan Khitan', karya M. Asrorun Ni'am Sholeh dan Lia Zahiroh, buku ini memaparkan ketentuan hukum dan praktik khitan. Buku Ensiklopedi Khitan (Kupas Tuntas Pembahasan Khitan dalam Tinjauan Syariat dan Medis) ${ }^{10}$, karya Dr. Andika Mianoki. Dalam buku ini dijelaskan sejarah khitan, hukum khitan, hikmah dan manfaat khitan dan waktu usia khitan. Juga termuat tips tentang khitan untuk anak dan orang tua yang mau mengkhitankan anaknya. Selain itu, buku ini juga mengulas khitan yang ditinjau dari syariat dan medis. Terakhir, Artikel Sunathrone Circumcision Device $^{11}$, karya Dr. Andi Berlian Tanwir yang menuliskan sejarah inovasi terhadap perangkat khitan Sunathrone Klamp serta manfaatnya untuk seluruh masyarakat.

Sejauh ini penelitian terdahulu dalam 1 dekade terakhir terkait Sunathrone Circumcision Device masih sebatas pada dunia kesehatan yang membahas akan efektivitas dan efiensi penggunaannya. Di antaranya penelitian yang dilakukan oleh Morris dan Elley ${ }^{12}$, Young ${ }^{13}$, dan Alawalmlh et al. ${ }^{14}$. Namun, pengkajian akan pengaitan antara penggunaan Sunathrone Circumcision Device dengan tinjauan hukum Islam tampak belum pernah dilakukan. Untuk itu, penelitian ini berupaya untuk mengupas tinjauan hukum Islam akan penggunaan Sunathrone Circumcision Device dalam khitan kaum muslimin, khususnya kaum adam (laki-laki).

\footnotetext{
${ }^{7}$ Sultan bin Ali bin Tsabit al-Jaradi. Al-Fawāid al Hisān Fi Ahkāmil Khitān. t.d.

${ }^{8}$ Sayyid Sābiq. Fiqih al-Sunnah. Juz 1. Cet. V; Bairut:Dar al-Fikr, 1971M/1391 H

${ }^{9}$ M. Asrorun Ni'am Sholeh and Lia Zahiroh. Hukum dan Panduan Khitan. Jakarta: Emir, 2018.

${ }^{10}$ Andika Mianoki. Ensiklopedi Khitan: Kupas Tuntas Pembahasan Khitan dalam Tinjauan Syariat dan Medis. t. Cet; t.t.p.: Kesehatan Muslim, t.th.

11 Sunathrone Circumcision Device. "Sunathrone Klamp". Situs Resmi Sunathrone Circumcision Device. http://sunathroneklamp.com/ (diakses pada 7 November 2019).

12 Morris, B. J., \& Eley, C. (2011). Male circumcision: An appraisal of current instrumentation. Biomedical Engineering, University of Rijeka, Rijeka, 315-354.

13 Young, H. (2013). Evolution of Circumcision Methods: Not "Just a Snip". In Genital Cutting: Protecting Children from Medical, Cultural, and Religious Infringements (pp. 69-83). Springer, Dordrecht.

14 Omar Al Hussein Alawamlh, et al. "Novel devices for adolescent and adult male circumcision." European urology focus 4.3 (2018): 329-332.
} 


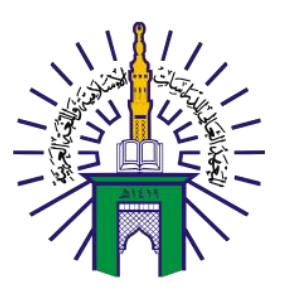

\section{BUSTANUL FUQAHA: \\ JURNAL BIDANG HUKUM ISLAM \\ Vol. 2 No. 2 (2021): Hal. 326-335 \\ EISSN: 2723-6021 \\ Website: https://journal.stiba.ac.id}

\section{PEMBAHASAN}

\section{Penerapan Metode Sunathrone Klamp di Smart Care Centre Makassar}

Smart Care Centre Makassar merupakan lembaga pengembangan kreativitas pemuda Indonesia yang bersifat edukatif, serta dilandasi dengan profesionalisme. Smart Care Centre didirikan di Kota Makassar, bertepatan dengan hari sumpah pemuda 28 Oktober 2015. Awal dari didirikannya Smart Care Center ini adalah klinik perawatan luka dan juga merupakan Event Organizer (EO) ${ }^{15}$. Adapun tujuan didirikannya Smart Care Center ini adalah menjadikan tempat praktik mandiri untuk perawat dan telah membuka kerja sama dengan dokter serta bidan. Smart Care Center bertempat di Kompleks Ruko Cendrawasih Mas D/9 Makassar. Adapun direktur utama sekaligus founder Smart Care Centre sendiri yaitu Ns Supriadi., S.Kep., CWCCA., CSN.

Visi Smart Care Centre adalah sebagai berikut; 1) Menjadi lembaga terkemuka dalam pengembangan tenaga kesehatan; 2) Menjadi wadah pengembangan kreativitas yang bersifat edukatif dan profesional; dan 3) Menjadi garda pelayanan kesehatan dalam meningkatkan derajat kesehatan masyarakat ${ }^{16}$. Adapun layanan yang tersedia pada klinik Smart Care Center sebagai berikut; 1) Layanan sunat modern Sunathrone Klamp; 2) Layanan perawatan luka modern; 3) Bekam; 4) Pelatihan BTCLS, HIPERKES, AK3 Umum, Sunat Modern, CWCCA, Bekam, Hipnoterapi; dan 5) Layanan Homecare.

Adapun metode pelayanan sunat atau khitan di klinik Smart Care Center hanya menggunakan Sunathrone Klamp. Sunathrone Klamp mulai digunakan pada bulan September 2018. Dengan alasan digunakannya bahwa alat ini dinilai higienis, sekali pakai dan lebih nyaman, sehingga risiko infeksi sangat rendah, serta pasien dapat beraktivitas dengan nyaman setelah berkhitan dengan Sunathrone Klamp ${ }^{17}$.

\section{Proses Penyembuhan Luka Setelah Khitan dengan Metode Sunathrone Klamp}

Penyembuhan luka khitan memiliki beberapa fase yang pada umumnya sama dengan penyembuhan luka lain, yaitu 3 pekan (21 hari) kulit akan seperti dalam bentuk semula. Adapun tahapan penyembuhan luka ada 3-4 fase: ${ }^{181920}$

a. Fase Hemostasis yaitu setelah kulit berdarah akibat insisi maka beberapa detik sel darah membentuk gumpalan darah berfungsi melindungi luka dan mencegah darah keluar lebih banyak, selain sel darah (trombosit) gumpalan tersebut mengandung protein disebut fibrin membentuk jaring agar gumpalan darah tetap pada tempatnya yang berlangsung selama 1-3 hari pasca insisi di mana luka pasca sirkumsisi tidak diperbolehkan kena air agar proses pada fase hemostasis dapat berlangsung dengan optimal.

\footnotetext{
${ }^{15} \mathrm{SP}$ (33 tahun), Founder Smart Care Center, Wawancara, Makassar, 6 April 2020.

$16 \mathrm{https}: / /$ smartcarecentre.wordpress.com/perihal-2/ (diakses 17/08/2021)

${ }^{17}$ SP (33 tahun), Founder Smart Care Center, Wawancara, Makassar, 6 April 2020.

${ }^{18}$ Howe, Robert.S.Van. (2020). Encyclopedia of Infant and Early Childhood Development (Second Edition).pages 273-280. https://doi.org/10.1016/B978-0-12-809324- 5.05785-0

19 Wahyuningrum, Ari Damayanti. "Perbandingan Metode Sirkumsisi Modern (Klamp dan Lem) Terhadap Proses Penyembuhan Luka Pasca Sirkumsisi pada Anak." Jurnal Ilmiah Kesehatan Media Husada 9.2 (2020): 82-87.

20 Sunathrone Circumcision Device. "Sunathrone Klamp”. Situs Resmi Sunathrone Circumcision Device. http://sunathroneklamp.com/
} 
b. Fase Inflamasi yaitu gumpalan darah mengeluarkan zat kimia yang menyebabkan peradangan seperti kemerahan, pembengkakan, nyeri yang mana sel darah putih akan menuju area luka dan melawan bakteri dan kuman di area tersebut dengan memproduksi zat kimia growth factors untuk memperbaiki jaringan rusak yang berlangsung selama hari ke empat pasca luka sirkumsisi. Ia juga merupakan respon biologis dan respon imunitas tubuh. Setiap luka akan mengalami fase ini. Dimulai saat terjadinya luka mulai hari ke-3 bertahan bisa sampai hingga 20 hari (selama nekrotik/kulit mati masih ada).

c. Fase Proliferasi yaitu tubuh akan membentuk kolagen jaringan baru pada hasil observasi kasat mata pada fase ini luka tampak memudar kemerahannya dimana terdapat sel kulit mati disekitar area luka yang berlangsung selama hari ke lima pasca sirkumsisi. Selain itu, pada tahap ini dianjurkan responden untuk rajin melakukan personal hygiene di area luka dengan dibersihkan dilakukan penyabunan ketika mandi (pembentukan sel baru), dimulai pada hari ke-7 dan bertahan hingga pekan ke-3. Pada waktu 2 pekan sampai 3 pekan ini, pasien dikhitan sudah tidak merasakan nyeri, bengkak menghilang, warna kemerahan di sekitar luka menghilang sehingga bisa dikatakan pada waktu ini luka khitan telah sembuh.

d. Fase Remodelling yaitu jaringan yang baru terbentuk saling menguatkan yang berlangsung mulai hari ke enam hingga beberapa hari atau pekan. Fase ini berlangsung 6 bulan hingga 1 tahun, dapat lebih lama bila luka yang bergerak aktif (sering ereksi). Luka bisa dikatakan sembuh sempurna bila telah terdapat ciri-ciri seperti tidak terlalu gatal, tidak menonjol, tidak memerah, dan lunak bila ditekan.

Ada dua faktor utama yang mempengaruhi proses penyembuhan kulit yang terluka; ${ }^{21}$ 1) Faktor umum yang meliputi usia, penyakit yang menyertai, kondisi pembuluh darah, status nutrisi, kegemukan, gangguan sensasi/pergerakan, status psikologis (stress/trauma), terapi radiasi, dan obat; dan 2) Faktor lokal yang meliputi kelembaban luka, penanganan luka, suhu luka, tekanan atau gesekan pada luka, benda asing dan kebersihan luka.

\section{Kelebihan dan Kekurangan Metode Sunathrone Klamp}

Praktik sunat dengan menggunakan metode Sunathrone Klamp memiliki kelebihan tersendiri dibanding dengan metode-metode yang lain. Kelebihan yang dimaksud di antaranya adalah;

a. Pasien yang telah berkhitan bisa menggunakan celana dan juga bisa kembali beraktifitas seperti biasanya tanpa harus berdiam diri di rumah sebagai tahap penyembuhan.

b. Sunathrone Klamp bersifat sekali pakai, sehingga penggunaannya tidak berulang seperti motode khitan lainnya.

c. Mengurangi waktu bedah dan tidak ada jahitan, sehingga menghemat waktu dan mencegah infeksi.

\footnotetext{
${ }^{21}$ Aminuddin, et al. 2020. Modul Perawatan Luka. Samarinda: CV Gunawana Lestari. Program Studi III Keperawatan Fakultas Kedokteran Universitas Mulawarman.
} 


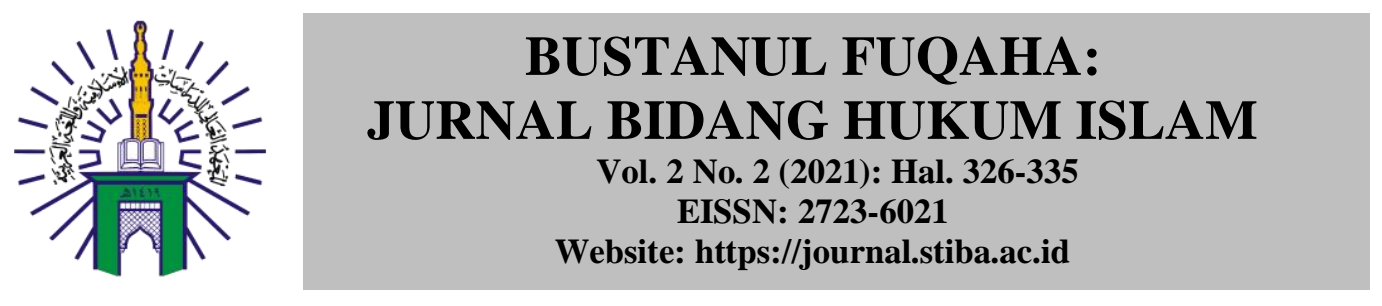

d. Proses penyembuhan luka relatif lebih cepat dibandingkan dengan metode-metode lainnya, serta dapat mengurangi risiko infeksi saluran kencing.

e. Sangat berpengaruh baik terhadap psikologi anak yang berkhitan dengan menggunakan alat ini, yaitu kurangnya rasa trauma dan stress terhadap anak akibat rasa sakit ketika berkhitan.

f. Menurut beberapa orang tua dari anak pasien yang berkhitan menggunakan Sunathrone Klamp bahwa penggunaan alatnya relatif cepat, mudah dan dapat mengurangi tingkat pendarahan ketika pembedahan. ${ }^{22}$

Adapun kekurangan menggunakan metode Sunathrone Klamp adalah sebagai berikut;

a. Kurangnya ketersediaan metode Sunathrone Klamp, karena dalam penggunaannya diperuntukkan untuk kalangan profesional.

b. Penggunaan metode ini memiliki standar operasional sehingga perlu adanya bimbingan khusus terkait penggunaan Sunathrone Klamp.

c. Sunathrone Klamp belum populer sehingga sifatnya masih kontradiktif (bertentangan) dikalangan masyarakat.

d. Pasien yang menggunakan metode ini akan merasakan kurang nyaman karena alatnya akan terpasang dalam beberapa hari.

e. Penggunaannya yang bersifat sekali pakai maka pembelian alat ini harus berulang sesuai dengan tingkat kebutuhan.

f. Menurut beberapa orang tua dari anak pasien yang berkhitan menggunakan Sunathrone Klamp bahwa biaya penggunaan alatnya tergolong mahal serta bentuk alat yang melekat pada kelamin anak cukup besar ${ }^{23}$.

\section{Pandangan Hukum Islam terhadap Praktik Khitan dengan Metode Sunathrone Klamp}

Tidak ada keraguan lagi bahwa ilmu kedokteran modern telah menemukan berbagai jenis pengobatan dan alat-alat medis yang tidak diketahui sebelumnya. Islam relevan dengan perkembangan zaman, Islam adalah agama rahmah lil alamin (QS.AlAnbiya/21:107) yang memiliki nilai kekhidupan sepanjang zaman dan berlaku untuk setiap generasi dan tempat. Inilah nilai rahmat Allah kepada manusia sebagai makhluk dinamis dan selalu berhasrah mengembangkan daya intelektualitasnya. Sebagai seorang muslim tentu harus mengikuti perkembangan zaman dengan memperhatikan kelayakannya serta kebolehannya dalam syariat Islam. Islam turut mengatur dan memberikan batasan-batasan tertentu dalam praktik khitan laki-laki dan perempuan. Menurut perspektif Islam khitan laki-laki mencakup sarana yang digunakan suci, tidak membahayakan, tujuannya untuk kepentingan yang tidak diharamkan, dan menghilangkan penutup kepala alat kelamin (Kulup) sehingga menjadi terbuka ${ }^{24}$.

Praktik khitan yang sesuai dengan syariat Islam merupakan patokan dalam implementasi praktik khitan secara medis. Sekalipun ada beberapa langkah yang dapat

\footnotetext{
${ }^{22}$ DABT (43 tahun), Creator Sunathrone Klamp, Wawancara, Makassar, 24 Oktober 2019.

${ }^{23}$ SP (33 tahun), Founder Smart Care Center, Wawancara, Makassar, 6 April 2020.

${ }^{24}$ M. Asrorun Ni'am Sholeh dan Lia Zahiroh, Hukum dan Panduan Khitan (Jakarta: Emir, 2018), h. 37.
} 


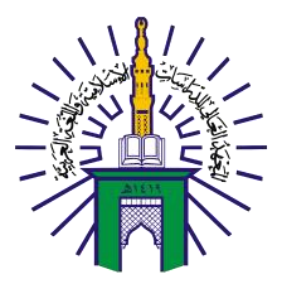

\section{BUSTANUL FUQAHA: \\ JURNAL BIDANG HUKUM ISLAM \\ Vol. 2 No. 2 (2021): Hal. 326-335 \\ EISSN: 2723-6021 \\ Website: https://journal.stiba.ac.id}

dilakukan dalam pelaksanaan khitan laki-laki, namun umumnya disesuaikan dengan kaidah kedokteran. Pemahaman terhadap khitan atau sunat sekarang tidak lagi bertumpu pada pada pendekatan syariat, tetapi telah meluas ke bidang kesehatan. Hal ini disebabkan dalam dunia kesehatan menganjurkan semua laki-laki harus berkhitan untuk terhindar dari berbagai macam penyakit. Sebagaimana diketahui, dunia medis melihat khitan atau sirkumsisi dalam dua aspek, yakni manfaat dan proses dari khitan itu sendiri. Syaikh Sa'ad bin Turki al-Khatslan memberikan penjelasan terkait masalah yang sama sebagai berikut:

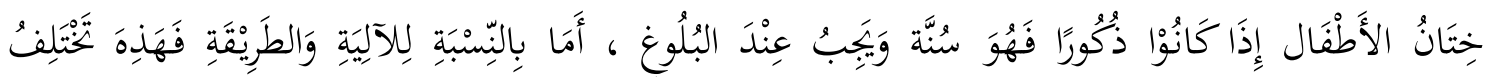

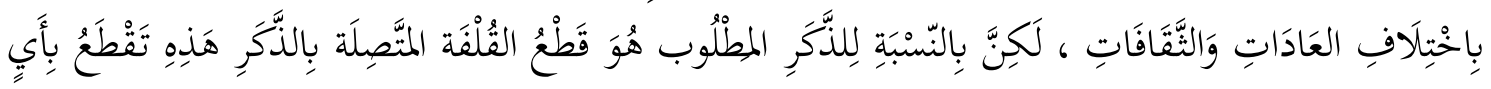

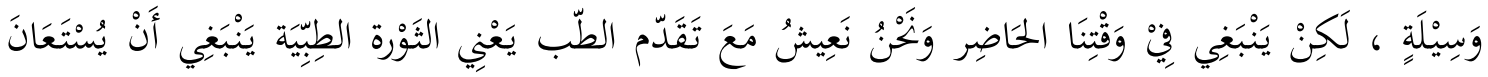

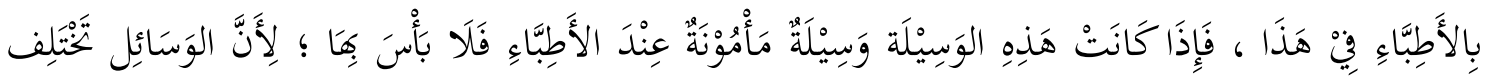

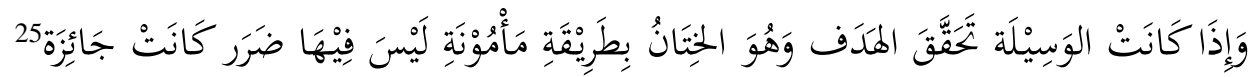

Artinya:

Khitan anak laki-laki, hukumnya sunah dan menjadi wajib ketika usia baligh. Adapun untuk alatnya, maka ini berbeda-beda sesuai perkembangan kebiasaan masyarakat dan teknologi. Hanya saja, terkait bagian dzakar yang diharapkan adalah terpotongnya qulfah (foreskin) yang bersambung dengan tudung dzakar. Kulit ini dipotong dengan cara apapun. Di zaman kita saat ini, dimana kita hidup di era kemajuan ilmu kedokteran, selayaknya meminta bantuan dokter. Jika cara yang digunakan adalah cara yang aman menurut dokter, hukumnya tidak masalah. Karena sarana itu berbeda-beda. Ketika sarana yang digunakan tersebut bisa mewujudkan tujuan khitan dengan cara yang aman, tidak membahayakan, maka hukumnya boleh.

Pendapat senada yang dikatakan oleh Dr. Berlian Tanwir bahwa apapun metode sunat atau khitan, jika tujuannya sama maka itu termasuk dari syariat Islam sendiri. Hal demikian dilihat dari pemilihan metode khitan yang memiliki beberapa resiko kemudian kedua dilihat dari segi dharar (bahaya) dari penggunaan alat ini. Banyak kasus di Indonesia penggunaan metode khitan yang berbahaya untuk anak contohnya metode besi panas $^{26}$. Uraian sebelumnya telah memberikan penjelasan terkait tujuan serta kelebihan dan kekurangan Sunathrone Klamp. Sunathrone Klamp adalah sebuah inovasi dalam dunia sirkumsisi untuk memberikan kenyamanan serta keamanan yang baik kepada dokter maupun pasien khitan.

Penjelasan di atas dapat dipahami bahwa penggunaan metode Sunathrone Klamp dalam praktik khitan dibolehkan dalam syariat Islam. Sebab ditinjau dari beberapa aspek

${ }^{25}$ Sa'ad bin Turki al-Khatslan, Fiqh al-Islam, (Riyadh: Darul Shoma'I, 2012), h. 398.

${ }^{26}$ DABT (43 tahun), Creator Sunathrone Klamp, Wawancara, Makassar, 24 Oktober 2019 


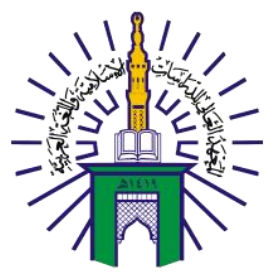

\section{BUSTANUL FUQAHA: \\ JURNAL BIDANG HUKUM ISLAM \\ Vol. 2 No. 2 (2021): Hal. 326-335 \\ EISSN: 2723-6021 \\ Website: https://journal.stiba.ac.id}

penting terkait pemakaian alat ini tidak mengandung bahaya serta memiliki tingkat keamanan yang baik, selama metode ini dilakukan oleh ahli medis yang profesional.

\section{KESIMPULAN}

Praktik khitan dengan menggunakan metode Sunathrone Klamp dibolehkan dalam hukum Islam. Islam turut mengatur dan memberikan batasan-batasan tertentu dalam praktik khitan sebagai syariat. Khitan bagi laki-laki dianggap cukup memotong kulup yang menutupi kepala zakar sehingga menjadi terbuka. Sunathrone Klamp adalah salah satu perangkat alat atau metode khitan yang dirancang untuk menghasilkan cara cepat, aman, dan canggih. Alat ini diciptakan dengan menggunakan teknologi plastik berfungsi sebagai penjepit yang dapat memotong kulit atau Kulup dengan tahapan menyembuhan melalui beberapa fase yaitu Fase Inflamasi (bengkak, merah, agak panas dan masih memiliki fungsi secara anatominya), Fase Proliferasi (pembentukan sel baru) serta Fase Remodelling (kekuatan luka meningkat dan pelunakan bekas luka).

\section{DAFTAR PUSTAKA}

\section{Al-Qur'an Tajwid dan Terjemahan}

Aminuddin, et al. 2020. Modul Perawatan Luka. Samarinda: CV Gunawana Lestari. Program Studi III Keperawatan Fakultas Kedokteran Universitas Mulawarman.

Alawamlh, Omar Al Hussein, et al. "Novel devices for adolescent and adult male circumcision." European urology focus 4.3 (2018): 329-332.

Al-Baihaqi, Abu Bakar Ahmad bin Ali. Sunan al-Kubra, Juz 8. Beirut: Dār al-Fikr, t.t. Al-Jaradi, Sultan bin Ali bin Tsabit. Al-Fawāid al Hisān Fi Ahkāmil Khitān. t.d.

Al-Khatslan, Sa'ad bin Turki. Fiqh al-Islam. Riyadh: Darul Shoma'i, 2012.

Hajrah, Hajrah. Khitan (Sunna) dalam Upacara Adat di Desa Bontocini Kabupaten Jeneponto. Diss. Universitas Islam Negeri Alauddin Makassar, 2017.

Mianoki, Andika. Ensiklopedi Khitan: Kupas Tuntas Pembahasan Khitan dalam Tinjauan Syariat dan Medis. t. Cet; t.t.p.: Kesehatan Muslim, t.th.

Morris, B. J., \& Eley, C. (2011). Male circumcision: An appraisal of current instrumentation. Biomedical Engineering, University of Rijeka, Rijeka, 315-354.

Sābiq, Sayyid. Fiqih al-Sunah. Juz 1. Cet. V; Bairut: Dār al-Fikr,1971 M/1391 H.

Sulahyuningsih, Evie, Yasinta Aloysia Daro, and Alfia Safitri. "Analisis Praktik Tradisional Berbahaya: Sunat Perempuan Sebagai Indikator Kesetaraan Gender dalam Perspektif Agama, Transkultural, dan Kesehatan Reproduksi di Kabupaten Sumbawa. "Jurnal Ilmu Keperawatan dan Kebidanan 12.1 (2021): 134-148.

Sholeh, M. Asrorun Ni'am dan Lia Zahiroh. Hukum dan Panduan Khitan. Jakarta: Emir, 2018.

Sunathrone Circumcision Device. "Sunathrone Klamp". Situs Resmi Sunathrone Circumcision Device. http://sunathroneklamp.com/

Tarazi, Norma. Wahai Ibu Kenali Anakmu: Pegangan Orang Muslim Mendidik Anak. Cet. I; Yogyakarta: Mitra Pustaka, 2001.

Van Howe, Robert.S. (2020). Encyclopedia of Infant and Early Childhood Development (Second Edition).pages 273-280. https://doi.org/10.1016/B978-0-12-8093245.05785-0 


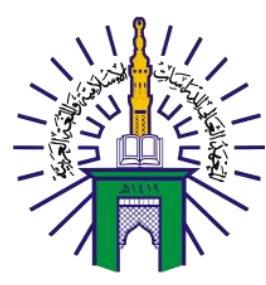

\section{BUSTANUL FUQAHA: \\ JURNAL BIDANG HUKUM ISLAM \\ Vol. 2 No. 2 (2021): Hal. 326-335 \\ EISSN: 2723-6021 \\ Website: https://journal.stiba.ac.id}

Wahyuningrum, Ari Damayanti. "Perbandingan Metode Sirkumsisi Modern (Klamp dan Lem) Terhadap Proses Penyembuhan Luka Pasca Sirkumsisi pada Anak." Jurnal Ilmiah Kesehatan Media Husada 9.2 (2020): 82-87.

Young, H. (2013). Evolution of Circumcision Methods: Not "Just a Snip". In Genital Cutting: Protecting Children from Medical, Cultural, and Religious Infringements (pp. 69-83). Springer, Dordrecht.

\section{Sumber Online}

https://smartcarecentre.wordpress.com/perihal-2/ (diakses 17/08/2021) 